IBIMA Publishing

Journal of e-Learning and Higher Education

https://ibimapublishing.com/articles/JELHE/2019/560996/

Vol. 2019 (2019), Article ID 560996, 13 pages, ISSEN : ISSN : 2169-0359

DOI : $10.5171 / 2019.560996$

Research Article

\title{
Classroom Evolution: The Swing Towards Blended and Flipped Learning
}

\author{
Rene Leveaux ${ }^{1}$, Sandra Gallagher ${ }^{2}$, Alan Sixsmith ${ }^{3}$ \\ And Helen Simpson ${ }^{4}$ \\ 1,3 University of Technology Sydney, Australia \\ ${ }^{2}$ Charles Sturt University, Australia \\ ${ }^{4}$ University of Wollongong, Australia
}

Correspondence should be addressed to: Rene Leveaux; rene.leveaux@uts.edu.au

Received date:10 October 2017; Accepted date:13 September 2019; Published date: 18 December 2019

Academic Editor: Mohamed Hussain Thowfeek

Copyright (C) 2019. Rene Leveaux, Sandra Gallagher, Alan Sixsmith And Helen Simpson. Distributed under Creative Commons CC-BY 4.0

\begin{abstract}
The predominant focus of eLearning information systems remains distance delivery and the blending of this distance education within the classroom. Comparatively, little work has been (or is being) undertaken to advance the use of technologies (eLearning) within the 'classroom only' situation as eLearning is not solely for distance education. Designing effective technologically founded educational learning that addresses the specific needs of class-based tertiary teaching is the main contribution of this article. Having online content that actively engages students both inside and outside the classroom can only occur following the critical evaluation of the modes of content selection and delivery. Furthermore, perfecting facilitator choices into the future about what technology and content used in which capacity, including whether it is online or face-to-face, would inevitably be valuable to both the learner and the teacher.
\end{abstract}

Keywords: eLearning, Blended Learning, Flipped Learning.

\section{Introduction}

In 1997, before the term eLearning became common place, learning guru Elliott Masie stated, "Online Learning is the use of network technology to design, deliver, select, administer, and extend learning"
(Masie, 1997). In his earlier work undertaken in 1998, Cross (2004 p. 104) noted, "eLearning is learning on the Internet over time, the convergence of learning and networks. eLearning is a vision of what corporate training can become. eLearning is to traditional training as eBusiness is to 
business usual". Then in 1999, Cisco expanded, "eLearning is Internet-enabled learning. Components can include content delivery in multiple formats, management of the learning experience, and a networked community of learners, content developers and experts" (Cross, 2004 p. 105). Research investigating the integration class-based technologies dates back more than 25 years, with the term 'eLearning' born from this integration (Papert, 1980).

Technology within the classroom is not a new concept. However, it has gained momentum over the past few years, with the advancement of technologies like smart phones and tablets. Smart phones and other devices have turned education into a much more versatile and flexible environment (Hajhashemi, Caltabiano, \& Anderson, 2017). Educators, many of whom are referred to as "digital immigrants" by Prensky (2001), have had to change the way they teach, and in doing so, have altered the depth of education that is offered to their students. Many teachers already have the background in pedagogical design to ensure the teaching methods they use align with lesson content, however, the introduction of technology has meant they must now reassess those designs to ensure the elimination of emergent inconsistencies with a digital framework (Hajhashemi et al., 2017).

Recently, there has been a shift in tertiary education towards flipped learning. A conventional definition for flipped learning is "work is given to the students to complete outside of the classroom so that they can prepare themselves for their next lesson" (Bishop \& Verleger, 2013). At face value, this differs little from past practices where academics handed out the entire curriculum in the first class and students would subsequently complete set components for the next class; a process dubbed 'homework'. However the fundamental difference between flipped learning and homework is that previously the teacher would mark students' completed homework to gauge individual comprehension, whereas flipped learning takes content to the next level; turning class time into discussions based on the understandings students develop during the prescribed pre-work (Davies, Dean, \& Ball, 2013).

Flipped learning is beneficial to students' knowledge acquisition and studying experience. Firstly, because the dialogue and strong teacher-student connection in the classroom empowers students (Lantis, Killie \& Krain 2010). Secondly, in flipped learning, there is the possibility to demonstrate the application of content within a real-time context. Even where students neglect to complete the pre-work, they are not disadvantaged as the focus of the first part of the lesson is on the 'flipped content'. This is particularly important as many academics would argue that 'most' students neglect the pre-work (Albert \& Beatty, 2014). Even so, this paper will demonstrate that the students do become actively involved in the flipped component of the course if the material is delivered attractively.

Many students only do the work required that is associated with marks (Albert \& Beatty, 2014). So how can academics ensure their students will complete class prework? One way is through interactivity; the process whereby educators and students work together and influence each other. This process is achieved with the students where the content is delivered correctly in both modes (flipped and in the classroom). Two ideas that can help achieve interactivity are:

1. Giving clear and concise instructions, and

2. Making sure that the work students are completing is relevant to the subject.

Although the above two items are common sense notions, they rarely occur when academics flip their classrooms. Moreover, some educators believe that just recording their lectures and putting them online is 'flipping' the classroom. When introducing flipped learning, academics need to source appropriate information and share this information in a simple to understand format that includes formative questions 
that enable students to test their understanding.

For students who remain unable to grasp concepts delivered in the flipped learning mode, the ability to ask questions in subsequent lessons and listen to the teacher discuss concepts with them and other students is imperative. Importantly, these classroom experiences also allow students with understanding to help those without, recreating the classroom as a conduit for 'peer learning' and providing teachers the opportunity to validate their content and determine if amendments are required.

Trial and error is a straightforward, simple way for academics to learn about the flipped classroom. Initially, this could be as simple as taking a flipped eLearning information system and using it with traditional face-toface teaching to enable effective collaboration in the classroom learning (Leveaux, Gallagher, \& Sixsmith, 2016). Nevertheless the incorporation of flipped learning into the classroom should be a carefully considered decision. It is not as simple as just giving students work to do at home and hoping that they will learn. For this reason, the process needs to be prudently planned by reflecting on the following questions:

- What content should be provided for students to learn outside of the classroom?

- How is that content relevant to the activities students will complete when they walk through the classroom door?

- How does one blend the best of face-to-face teaching with online content?

All three are considerations facing current academics trying to give the students an authentic learning experience. Other factors which are also fundamental to blended learning include:

- The type of information system to be used

- The style of the content

- The service delivery of the content and
- The engagement of the students.

The format of this paper commences with literature in the area of blended learning, educational design concepts and eLearning. This is then followed by the context of the research, discussion on transitioning with flipped and blended learning, conclusion and future work.

\section{Blended Learning: Utilises Learning Resources with Traditional Face-to-Face Methods}

Blended Learning (BL) is a combination of both online and face-to-face modes of learning (Abdellatief et al 2011; Holsapple \& Lee-Post, 2006; Leveaux, Gallagher, \& Sixsmith, 2016). According to Rauch and Crawford (2012), BL offers the best of both delivery systems (Rauch \& Crawford 2012). A number of positive attributes have been linked to BL. These include an increase in students' perception of their self-value (Cox \& Orehovec 2007), a reduction in student withdrawals from courses (Tinto 1993) and an increase in student satisfaction with learning and GPAs (Astin 1993). One of the reasons may be its incorporation of eLearning and information systems.

A diverse range of articles reflects the nature of eLearning and information systems (Al-Qahtani \& Higgins, 2013; Anohah, Oyelere \& Suhonen 2017; Davies et al., 2013). The most notable topics of discussion regarding eLearning information systems (ELIS) over the past decade cover the areas of content, delivery methods, quality of delivery, pedagogy and design. Situated learning (Lave, 1996) or the creation of meaning through every day learning experiences is a fundamental element in engaging students. This is because participating in familiar activities that maximize learning allows students to grasp not only the intended outcomes but also the underlying context of an activity. Learning then becomes an experience and provides students with the knowledge to perform efficiently (Gallagher \& Sixsmith, 2014).

Recently, pedagogy has shifted "away from an exclusively individualistic, psychological 
view on learning toward a perspective of learning involving participation in social interactions within the context of a community" (Gallagher \& Sixsmith, 2014). This is because when students enjoy a class, they are more likely to achieve better outcomes, keep their attention levels high and thereby, improve understanding of the content delivered. Engaging students in the learning process is particularly relevant when undertaking subjects that provide content not typically implicit to their field of study.

ELIS services are a crucial, strategic, organisational asset and therefore, appropriate levels of resources to support, deliver and manage these systems are required. Evaluating blended learning is not easy as ELIS are only one part of what is occurring in the classroom and are often hidden. For this reason if IT students are asked about in class activities, they typically state that there are no IT components in their classroom. Such comments make it hard to relate the quality of digital learning activities undertaken by students. Moreover, if one focuses on an overall methodology asking if the approach of an ELIS and classroom paper-based activities complement each other, student and instructor perceptions may differ.

Regardless, an important goal of ELIS is to deliver instructions that produce equal or better outcomes than face-to-face learning systems (Eom, Ashill, Arbaugh \& Stapelton 2012)]. Moreover, facilitators require an understanding of relationships between eLearning systems quality, the quality of information produced by eLearning systems and eLearning outcomes. Educational technology has grown to be ruled by an (often-abstracted) interest in the processes of how people learn with digital technology (Eom et al. 2012; Selwyn, 2010). Integrating blended learning into the classroom through the utilisation of an ELIS that encourages students to undertake prework then attend class, provides the advantage of extended discussion time in class and with that the expansion of higher order learning experiences. Experiences that facilitate the grasping of key concepts, increased interaction and extended access to hands-on activities (Howet \& Pegrum, 2015; Mar, 2005).

\section{Educational Design Concepts}

Education is a result of instruction and learning. Educational, instructional and learning design are interchangeable depending on the environment. Many universities, such as the University of Technology Sydney (UTS), have established that rolling out instructional design concepts is necessary, however they have not known how to approach this challenge. Instructional design changes at UTS have included (1) putting some introductions to classes online, via video, (2) limiting the length of class time to a maximum of three hours face-to-face and (3) ensuring that students were encouraged to experience the best of online and face-to-face learning.

In the years prior to the introduction of inclassroom technology, teachers relied on various modes of education delivery with content they created using well-known textbooks or using other teachers' hand written or typed notes. The introduction of technology into the classroom has led to a fundamental shift in education, which many universities are finding difficult. Educators need to step back and look at the learning from a student's view (Beetham \& Sharpe, 2007).

Technology should support learning not drive it. Knowing how much technology to incorporate into the classroom is a balancing act. Many teachers overpower learners with so much technology that learning becomes irrelevant. Students become overwhelmed. This leads to complacency in their learning and in turn negative feedback to teachers about the learning process (Davies et al., 2013). Finding a happy medium is not straightforward as students need to have access to technology via a Learning Management System (LMS), which they access via a digital device, such as a smart phone, laptop or computer. Then teachers need to incorporate the appropriate level of technology, which could be a voting system, an online quiz or a video into their classroom. However this should be limited 
to ensure no shift in the focus of the educational outcomes from students to teachers (Beetham \& Sharpe, 2007).

\section{e-Learning}

eLearning has evolved over the years and currently appears to be at the forefront of many institutions across the globe despite issues with its integration into classrooms. Many educational and industry based learning organisations have fast tracked eLearning's introduction and incorporated technology without much consideration (Deakin, 2016). With little effort, one can search on the Internet and find many hasty online content delivery models. For instance, uploading a webinar without providing the context for watching and hoping that students will view and learn from it is not eLearning. It is simply the provision of a seminar in an online format.

Due to the ease of access, Massive Online Open Courses (MOOCs) are widely used by many institutions to deliver content. However these courses are mainly designed for distance education not requiring interaction(s) with a teacher, and lend themselves primarily to students learning at their own pace. Flipped or blended learning involves certain interactions between students and students or students and teachers, which, in itself, does not align the concept of MOOCs.

The convenience of eLearning systems appears to have overridden the learning design component of synthesising different learning and teaching styles commonly applied in the delivery of courses. Before technology was introduced within the educational sector, educators used frameworks or taxonomies to help them make sense of the content for students; the most common Blooms Taxonomy (Bloom, 1956) remains in use today. Bloom's taxonomy has been applied in education since 1956 when Benjamin Bloom wanted to make logic of the learning of students.

Another teaching and learning framework that has evolved with the introduction of technology in the classroom is Kolb's
Framework (Kolb, 1984). Much of Kolb's theory is concerned with the learner's internal cognitive processes. Within this schema "learning is the process whereby knowledge is created through the transformation of experience" (Kolb, 1984, p. 38). Both Kolb's (1984) and Bloom's (1956) frameworks continued to be popular and have been utilised by teachers in classroom delivery for many years. Regardless, with the introduction of technology in the classroom, teachers need to understand what eLearning means with regards to individual teaching styles and how this integrates with their institutional teaching and learning strategies in order to enable seamless integration of the ELIS into the classroom.

With this in mind, it would be beneficial for institutions to re-approach their teaching and learning strategy and instead of singularly pushing for a top-down approach, requiring teachers incorporate technology into each course, they utilise the strategy of dual top-down, bottom-up approaches. A starting point worth considering could include management working in consultation with a few teachers using one piece of technology. This is because consultation and starting simply encourages teachers to incorporate technology in their teaching (Mishra \& Koehler, 2006). Furthermore, giving thought to how and which technology to use enables a greater efficiency when rolling out teaching technology across the institution. Top-down approaches should always be directed in such a fashion that does not increase pressure on the educators and where the reasoning behind the integration makes sense to the educational outcome for all those involved.

Many institutions erroneously remain too general and deliver eLearning strategy in an ad-hoc manner, creating confusion and panic amongst teachers (Hill, Jones, \& Schilling, 2014). Mishra \& Koehler (2006) highlight that teaching is a complex cognitive skill that occurs in an illstructured, dynamic environment (Mishra \& Koehler, 2006). Introducing technology in an ad-hoc manner brings about misunderstandings regarding what 'real' 
teaching and learning strategy is. The flow on effect is that some teachers upload content onto the LMS with no prior fore thought. As already argued, taking classroom based learning and uploading it onto an LMS does not constitute eLearning, rather it is using the LMS as a document content library; a process with no pedagogical reasoning behind it. Students simply become receivers of paper-based learning that has been digitised. This form of teacher complacency occurs as a result of a singular top-down approach due to a complete misunderstanding of technology use within education (Guri-Rosenblit, 2005; Hill et al., 2014).

Understanding the different meanings of eLearning and what can be done to implement technology within the classroom, such as choosing one or two outcomes rather than all, is a great starting point for institutions to discuss with internal learning designers. This process should start by understanding eLearning typologies. Numerous typologies of eLearning exist, some are:

- Asynchronous eLearning: A student-centered method of learning where people are not online at the same time and interaction occurs with a time delay, allowing people to participate when it suits their schedules (Reform, 2017)

- Self-Study: Which addresses the distinct learning needs, interests of individual students. (Hill et al., 2014)

- Discussion Groups: These allow for peer-to-peer support and learning. Subject matter experts can add their support to the discussion to build on the peer-topeer learning that is occurring (Selim, 2007)

- Distance Education: This allows the students to self-pace through the online content. There are usually no set times for distance classes (Jenkins, Rumble, Murugan, et al. 2017)

- Synchronous eLearning: Learning where people are online at the same time (Chen, 2017)

- Virtual Classroom: An online classroom that allows participants to communicate, view presentations, interact with learning resources and work in groups. Virtual classrooms can be used to hold lectures and tutorials online, a feature particularly useful to external students. Virtual classrooms can also be setup as online meeting spaces for students to work on group tasks (Radu, Southgate, Ortega, et al. 2017)

- Audio and video conferencing: This includes the use of the sites: Google Hangouts, Adobe Connect and GoT0webinar. Webinars, or seminars held online, are modes of video conferencing. Typically webinars are recorded for later viewing (Gault, 2017)

- Blended Learning: This is a combination of online and face-toface delivery (Abdellatief, Sultan, Jabar, \& Abdullah, 2011; Holsapple \& Lee-Post, 2006; Leveaux, Gallagher, \& Sixsmith, 2016).

The above typologies indicate that the term eLearning is quite broad and expresses many forms of digital content delivery. To date, there is no agreed definition of the word 'eLearning', and as a result, many researchers when using the term eLearning are indicating the terms 'blended', 'online', 'virtual' and 'distance' interchangeably. This creates confusion amongst researchers and teachers alike as inconsistent semantics typically create misperception and misattribution of reasoning.

\section{Context of the Research}

This comparative case study employs an interpretive approach, as the intent is to understand the impacts of flipped and blended learning from the perspective of participating student cohorts. In using an interpretive approach, the researcher has sought to gain a deeper understanding of the area under study and the context within which the research data was gathered (Crotty 1998). 
One of the considerations of this study was the best way to incorporate technology into the classroom. Research has shown that user satisfaction is a crucial factor in assessing eLearning success, in particular, learner dissatisfaction with eLearning integration within the classroom and the ease of use of required systems by students (Alsabawy \& Cater-Steel, 2012). Other research concurs that highlighting user satisfaction is the key driver to the continuing use of eLearning (Al-Omari, Carter, \& Chiclana 2016).

This research centres on a case study of student responses to surveys regarding their experiences with IT subjects. Hamel et al. (1993: p45) define a case study as an 'indepth investigation using different methods to collect information and to make observations', during which 'empirical' evidence assists in understanding the 'object of the study'. By conducting a case study, researchers can explore the significant features of a case and create credible interpretations from the everyday experiences of participants (Crotty 1998). Case study research provides an in-depth understanding of the context under study and increases our understanding of a given situation (McGovern 2003, Morse and Richards 2002, Yin 2003).

The focus of this case study was two university information systems subjects within our faculty at the University of Technology Sydney: Finance and IT Professionals (undergraduate) and Project Management (post-graduate), The sampling occurred over a three-year period from second semester 2013 to first semester 2016 inclusive. During that period, the undergraduate subject was only taught in the first semester of each year whilst the postgraduate unit was delivered each time across a full year. These subjects contained some non-IT specific content, which, when presented in a new flipped learning genre, was considered potentially to be a major issue for academic teaching staff.

Data was collected from the standard university online student feedback survey (SFS) conducted at the completion of each semester, with survey results forming the basis of a comparative study of integrating eLearning that involved the use of pre-work or flipped learning via ELIS. The online SFSs questions required five scaled answers (quantitative data) and two freeform answers (qualitative data).

Using thematic analysis, preliminary themes were uncovered from the data. Through a consolidation process, dominant themes emerged from the identified preliminary themes (Attride-Stirling 2001; McGovern 2003; Morse \& Richards 2002). Two dominant themes emerged from this qualitative data: using the ELIS, and flipped learning pre-work content.

This research, as stated earlier, is based on two subjects, Finance and IT Professionals (undergraduate) and Project Management (post-graduate), which incorporated the use of an ELIS. Table 1 (below) charts student comments about both subjects, largely focusing on the style of content made available to them. The results show students perceived multiple versions of the same content to be counter-productive and "doubling up" on subject resources, potentially influencing subject efficiency and effectiveness.

\section{Using the ELIS}

Successful integration of ELIS into coursework subjects is not new and is well documented in the literature. Research into students who participated in a trial of eLearning versus traditional learning, found eLearning was an effective method that deepened the student understanding of the subject (Abdellatief et al, 2011; Alsabawy \& Cater-Steel, 2012). Furthermore, Jones and Gregor (2006) found that learning supported by an IS gave students a distinct advantage in their coursework. Student comments collected in the current data supported each of these findings.

Many student comments regarding both subjects in this study (see table 1) focussed on the style of content made available. It was perceived that the content was in a format that did not suit the learning needs of particular students. Equally, multiple versions of the same content were recorded 
by students to be counter-productive and "doubling up" on subject resources and

potentially impacting subject efficiency and effectiveness.

Table 1: Student comments regarding the ELIS

\begin{tabular}{|c|c|}
\hline Positive & Negative \\
\hline $\begin{array}{l}\text { "Videos came with weekly content to help } \\
\text { understand financial principles etc." (F\&IT) }\end{array}$ & $\begin{array}{l}\text { "Use lecture slides instead of web-based } \\
\text { learning materials" (F\&IT) }\end{array}$ \\
\hline $\begin{array}{l}\text { "The subject materials were well organised" } \\
\text { (F\&IT) }\end{array}$ & $\begin{array}{l}\text { "Lack of connection between the tutorials and } \\
\text { the lecture materials" (F\&IT) }\end{array}$ \\
\hline “online videos in lectures helped” (F\&IT) & $\begin{array}{l}\text { "the content of this subject was so poorly } \\
\text { handled.there were online modules that were } \\
\text { supposed to be done before the lesson, but } \\
\text { then were not gone through in the lesson." } \\
\text { (F\&IT) }\end{array}$ \\
\hline $\begin{array}{l}\text { "All learning material is available online." } \\
(\mathrm{PM})\end{array}$ & $\begin{array}{l}\text { "I would suggest that the content also be } \\
\text { available in PDF version for those of us that } \\
\text { like to sit down and highlight stuff ... content } \\
\text { on the computer is too distracting for me } \\
\text { cause of my attention span " (F\&IT) }\end{array}$ \\
\hline $\begin{array}{l}\text { "I was interested in the sequence of the } \\
\text { teaching as each week we built on items from } \\
\text { previous weeks to create a fuller picture of } \\
\text { the methodology." (PM) }\end{array}$ & $\begin{array}{l}\text { "It would be better if you could provide } \\
\text { pdf/slides of all lectures" (PM) }\end{array}$ \\
\hline $\begin{array}{l}\text { "This lecture provides the video class for } \\
\text { learning, ... I think it is quite good for PM } \\
\text { trying to provide video class to enhance the } \\
\text { learning and teaching outcome" (PM) }\end{array}$ & $\begin{array}{l}\text { "better templates. examples of templates in } \\
\text { use, more relevant case studies and } \\
\text { assignments." (PM) }\end{array}$ \\
\hline $\begin{array}{l}\text { "Lots of resources were provided, and the } \\
\text { subject was fun to learn" (PM) }\end{array}$ & $\begin{array}{l}\text { "The subject materials online should be } \\
\text { available in one package only - } \\
\text { PDF/PowerPoint and video, and not } \\
\text { segregated into parts" (PM) }\end{array}$ \\
\hline
\end{tabular}

\section{Flipped Learning Pre-Work Content}

Prior to 2014, classes in the traditional model consisted of a $1 \frac{1}{2}$ hour lecture and a series of $1 \frac{1}{2}$ hour tutorials. Within this context, Finance and IT (F\&IT) had one (1) lecture and six (6) tutorials (10 $1 / 2$ hours of class time) and Project Management (PM) had one (1) lecture and four (4) tutorials (7 $1 / 2$ hours of class time). Under the new model, F\&IT was delivered in two, 2-hour workshops and PM was delivered via two, 3hour workshops.

Collaborative classrooms were used to facilitate group work activities with the presumption that students had completed pre-work content prior to the class. This teaching mode, whereby each student comes prepared, encouraged greater student interaction in the classroom. The use of collaborative classrooms for these subjects again increases interaction. Depending on the subject, F\&IT or PM, the degree of pre-work content varied depending upon the teaching objectives for individual weekly classes. In essence, prework for both subjects undertaken prior to the class was intended to take students on a journey through various weekly scenarios aimed at consolidating subject content. However, from the student's comments (see table 2 below) most negative comments 
focused on this class structure with the traditional style of a lecture and tutorial nominated as more suitable than the flipped nature of the class. On a positive note, some comments focused on the new learning style and its ability to providing an environment in which students perceived they were easily able to work collaboratively to discuss ideas and concepts related to the weekly scenarios.

Table 2 shows a mixed reaction to the new teaching style. Most negative comments for F\&IT concerned perceptions of disparity between the subject's 'theory' and 'practical' content. Students' focus on theory is surprising as research shows one of the best ways to learn topic content is through practical application (reference) - in this case scenario based learning. Regardless, positive student comments all supported the practical aspect of each subject. Student perceptions of PM were more positive overall. In particular they were appreciative of both content and practical work, citing relevance to career options. Again, scenariobased learning was the basis of the practical work in this subject.

Table 2: Student comments regarding the flipped subject delivery method

\begin{tabular}{|c|c|}
\hline Positive & Negative \\
\hline $\begin{array}{l}\text { "The structure of the classes, allowing } \\
\text { students to work together to complete an } \\
\text { exercise without a tutor trying to control } \\
\text { exactly how and when the work is done } \\
\text { really helped all the students stay } \\
\text { motivated." (F\&IT) }\end{array}$ & $\begin{array}{l}\text { "More integration between notes and what } \\
\text { we were actually doing would also have } \\
\text { been really wonderful." (F\&IT)) }\end{array}$ \\
\hline $\begin{array}{l}\text { "The learning environment for this subject } \\
\text { was well organised" (F\&IT) }\end{array}$ & $\begin{array}{l}\text { "Content needs to be shown more like a } \\
\text { lecture" (F\&IT) }\end{array}$ \\
\hline "The weekly challenges were great" (F\&IT) & $\begin{array}{l}\text { "Content could be more relevant to tested } \\
\text { material" (F\&IT) }\end{array}$ \\
\hline $\begin{array}{l}\text { "Practical based assignment and weekly } \\
\text { quizzes (which forced students to actually } \\
\text { look at and do the work)" (F\&IT) }\end{array}$ & $\begin{array}{l}\text { "[Classes] had little to do with the overall } \\
\text { content given" (F\&IT) }\end{array}$ \\
\hline \multirow[t]{2}{*}{$\begin{array}{l}\text { "Good ideas and an innovative approach to } \\
\text { presenting the subject matter". (F\&IT) }\end{array}$} & $\begin{array}{l}\text { "The subject structure, the idea of workshop } \\
\text { makes students focus on the theory part of } \\
\text { the subject less." (F\&IT) }\end{array}$ \\
\hline & $\begin{array}{l}\text { "Tutorials are too vague with too many } \\
\text { students in each class" (F\&IT) } \\
\text { "Please make this subject more structured } \\
\text { and interrelated" (F\&IT) }\end{array}$ \\
\hline $\begin{array}{l}\text { "I like the workshop in every class that we } \\
\text { can discuss in a group" (PM) }\end{array}$ & $\begin{array}{l}\text { "The out-of-class preparation material, } \\
\text { many people wouldn't do it - maybe add } \\
\text { marks to it" (PM) }\end{array}$ \\
\hline $\begin{array}{l}\text { "Lots of emphasis on Workshopping the } \\
\text { Theory" (PM) }\end{array}$ & $\begin{array}{l}\text { "I suggest that the way of teaching and } \\
\text { answering by the tutor should be more } \\
\text { flexible" (PM) }\end{array}$ \\
\hline $\begin{array}{l}\text { "All the topics were really helpful and } \\
\text { practical. I've enjoyed this project a lot!" } \\
(\mathrm{PM})\end{array}$ & $\begin{array}{l}\text { "The only part of the learning material I did } \\
\text { not enjoy was the Lynda videos." (PM) }\end{array}$ \\
\hline
\end{tabular}

Rene Leveaux, Sandra Gallagher, Alan Sixsmith And Helen Simpson, Journal of e-Learning and Higher Education, DOI: 10.5171/2019.560996 
"The presentations and learning activities were both engaging and enjoyable, as well as enabling the content to be understood in

a practical holistic manner (PM)

\section{To Flip or Not to Flip?}

In light of these findings: should educators flip their classroom or not? The answer is not as straight forward as it first appears. Flipping the classroom requires considerable time, something many academics do not have.

The first step is to start small, by finding information that meets the threshold of students' understanding and is suitable to enable students to learn all aspects of course material. For instance bridging students' knowledge of the difference between the terms 'debit' and 'credit' with a simple explanation. Once content is resolved, the second step is to determine how that content will be delivered to students and by which medium. A facilitator may ask themselves, 'will a PowerPoint be sufficient or does the facilitation also require a video (PowerPoint with associated audio) and if so, 'will a more professional video be required?' Noting that professional audio-visual recordings may give students the ability to watch content on any device, anywhere.

Regardless of the medium used or the content delivered, the decision on whether to flip or not to flip a class is dependent on several factors. These include the availability of resources (such as support staff and funds for subject revision and / or needed equipment), the content and learning objectives of the subject (e.g. theoretical or practical), and the flexibility of the academic staff to accept and implement change. In the words of one surveyed F\&IT student, "we were given the freedom to collaborate and work with almost everyone in the tutorial. It is a distinct quality of this subject, which I greatly appreciate! It made the learning experience enthusiastic". This comment reinforced our decision to flip these subjects

\section{Conclusion and Future Work}

As educational technology and associated fields continue to evolve, conflicting findings have emerged regarding eLearning environments. In education today, a paradigm shift is underway which involves critical challenges for universities to enhance innovation in teaching and learning. Universities have been quick to embed technology into the classroom. However, it has taken, and is still taking, a long time to work out the most efficient way to incorporate an ELIS and ensuring its effectiveness. The fundamental problem is that often the classroom has had too many alternative technologies implemented. This does not adequately support blended learning. Equally educators, when using an ELIS, have at times attempted to add too much technology too soon. Both aspects need to be ameliorated with the frame of the students' overall learning experience in mind.

Research on collaborative or blended learning has indicated that although student engagement remains limited initially, flipped learning experiences and the blended learning environment in the longer-term assist students in understanding threshold concepts. However, more studies in this area are required. Future research needs to broaden its exploration of the use of ELIS within the classroom. In particular, research should consider student focus groups, as these would be beneficial in assisting researchers to delve further into this study's findings and to discover the 'real' reason why students find changes in delivery styles difficult to cope with. In conjunction with this research, is underway to trial of an industry-based framework for ELIS integration as in practice this would assist with the alignment of subjects to the ELIS framework. 


\section{Notes}

Classroom: Classroom in this study refers to on-campus teaching facilities at the tertiary level.

A Webinar: Webinar refers to a recorded online session, either delivered synchronous or asynchronous

\section{References}

1. Abdellatief, M., Sultan, A., Jabar, M. A., \& Abdullah, R. (2011). A Technique for Quality Evaluation of E-Learning from a Developers Perspective. American Journal of Economics and Business Administration, 3(1), 157-164.

2. Albert, M., \& Beatty, B. J. (2014). Flipping the Classroom Applications to Curriculum Redesign for an Introduction to Management Course: Impact on Grades. Journal of Education for Business, 89(8), 419-424. doi:10.1080/08832323.2014.929559

3. Al-Omari, M., Carter, J. \& Chiclana, F. (2016). A hybrid approach for supporting adaptivity in e-learning environments. The International Journal of Information and Learning Technology, 33(5), 333-348.

4. Al-Qahtani, A. A., \& Higgins, S. E. (2013). Effects of traditional, blended and elearning on students' achievement in higher education. Journal of computer assisted learning, 29(3), 220-234.

5. Alsabawy, A. Y., \& Cater-Steel, A. (2012). Identifying the Determinants of $E$ Learning Service Delivery Quality. Paper presented at the 23rd Australasian Conference on Information Systems, Geelong

6. Anohah, E., Oyelere, S. S., \& Suhonen, J. (2017). Trends of mobile learning in Computing Education from 2006 to 2014: A systematic review of research publications. International Journal of Mobile and Blended Learning (IJMBL), 9(1), 16-33.
7. Astin, A. W. (1993). What matters in college? Four critical years revisited. San Francisco: Jossey- Bass

8. Attride-Stirling, J., (2001) Thematic networks: an analytic tool for qualitative research, Qualitative Research, (1, 3): pp 385-405.

9. Beetham, H. \& Sharpe, R. (2007) Rethinking Pedagogy for a digital age: designing and delivering e-learning. Routledge: Abingdon

10. Bishop, J. L., \& Verleger, M. A. (2013, June). The flipped classroom: A survey of the research. In ASEE National Conference Proceedings, Atlanta, GA (Vol. 30, No. 9).

11. Bloom, B.S., 1956. Taxonomy of educational objectives. Vol. 1: Cognitive domain. New York: McKay

12. Cox, B. E., \& Orehovec, E. (2007, Summer). Faculty-Student interaction outside the classroom: A typology from a residential college. Review of Higher Education, 30(4), 343-362

13. Cross, J. (2004). An Informal Histroy of eLearning, On the Horizon, $(12,3)$ pp.103-110

14. Crotty, M. (1998) Foundations of Social Research: Meaning and Perspective in the Research Process, Allen \& Unwin, Sydney

15. Davies, R. S., Dean, D. L., \& Ball, N. (2013). Flipping the classroom and instructional technology integration in a college-level information systems spreadsheet course. Educational Technology Research and Development, 61(4), 563-580.

16. DeakinPrime. (2016) Engineering Students:- Industry Requirements multiple surveys, DeakinPrime, Melbourne

17. Eom, S, Ashill, N, Arbaugh, J Stapelton, J (2012) Human systems Management, Vol 31, No. 3-4 pp. 147-163

18. Gallagher, S., \& Sixsmith, A. (2014). Engaging IT undergraduates in non-IT content: Adopting an eLearning Information System in the classroom. 
Interactive Technology and Smart Education, 11(2), 99-111

19. Gault, A. (2017). elearning for Adobe Photoshop and Illustrator in Textiles and Fashion. Paper presented at the The International Scientific Conference eLearning and Software for Education.

20. Guri-Rosenblit, S. (2005). 'Distance Education' and 'e-learning': Not the same thing. Higher Education, 49(2005), 467 - 493.

21. Hajhashemi, K., Caltabiano, N., \& Anderson, N. (2017). Integrating digital technologies in the classroom: Lecturers' views on the flipped classroom approach. Australian and International Journal of Rural Education, 26(3), 18-29.

22. Hamel, J. with Dufour, S. \& Fortin, D. (1993) Case Study Methods, Sage Publications, Newbury Park, California

23. Hill, C. W., Jones, G. R., \& Schilling, M. A. (2014). Strategic management: theory: an integrated approach: Cengage Learning.

24. Holsapple, C. W., \& Lee-Post, A. (2006). Defining, Assessing, and Promoting ELearning Success: An Information Systems Perspective*. Decision Sciences Journal of Innovative Education, 4(1), 67-85. doi:10.1111/j.15404609.2006.00102.x

25. Howett, C \& Pegrum, M. (2015) Implementing a flipped classroom approach in post graduate: An unexpected journey into pedagogical redesign Australasian Journal of Educational Technology, 31 (4)

26. Jenkins, J., Rumble, G., Murugan, K., Koul, B., Dodds, T., Peters, O., \& Perraton, H. (2017). Unit-9 Characteristics of Distance Education: IGNOU.

27. Jones, D., \& Gregor, S. (2006) The formulation of an Information Systems Design Theory for e-learning, First International Conference on Design Science Research in Information Systems and Technology, Claremont, CA.
28. Kolb, D. A.(1984) Experiential Learning. Englewood Cliffs, $\mathrm{N}$ J:Prentice-Hall.

29. Lantis, J.S., Kille, K.J. and Krain, M., (2010) The state of the active teaching and learning literature. In Oxford Research Encyclopedia of International Studies.

30. Lave, J. (1996) Teaching, as Learning, in Practice, Mind, Culture and Activity, Vol 3, pp. 149-164.

31. Leveaux, R., Gallagher, S., \& Sixsmith, A. (2016). Creating a Situated Learning Environment in the Classroom for Final Year IT Students. Paper presented at the 28th IBIMA.

32. Mar, N. (2005). Utilizing Information and Communication Technologies to Achieve Lifelong Education for All: A Case Study of Myanmar. Educational Research for Policy and Practice, 3, 141166.

33. Masie, E. (1997). Seizing your intranet. Training \& Development, 51(2), 51-53.

34. McGovern, Y. (2003) The Practice of Market and Social Research, Pearson Education FT Prentice Hall, Harlow, England

35. Mishra, P., \& Koehler, M. J. (2006). Technological pedagogical content knowledge: A framework for teacher knowledge. Teachers college record, 108(6), 1017.

36. Morse, J.M. \& Richards, L. (2002) Readme First for a User's Guide to Qualitative Methods, Sage Publications, Thousand Oaks, California.

37. Papert, S. (1980). Mindstorms: Children, computers, and powerful ideas. Basic Books, Inc.

38. Prensky, M. (2001). Digital natives, digital immigrants part 1 . On the Horizon, 9(5), 1-6.

39. Radu, I., Southgate, E., Ortega, F. and Smith, S., (2017) March. Summary: 2017 IEEE virtual reality second workshop on K-12 embodied learning through Virtual \& Augmented Reality (KELVAR). In 2017 IEEE Virtual Reality Workshop on K-12 Embodied Learning 
through Virtual \& Augmented Reality (KELVAR) (pp. 1-2). IEEE.

40. Rauch, D.W., \& Crawford, E. K. (2012) Cohorts, communities of inquiry and course delivery methods UTC best practices in learning - The hybrid learning community model. The Journal of Continuing Higher Education, 60, 175-180. Doi: $10.1080 / 07377363.722428$

41. Reform, E. (2017). The Glossary of Education Reform, for Journalists, Parents and Community Members. [Online] [Retrieved June 28, 2017] http://edglossary.org/asynchronouslearning/
42. Selim, H. M. (2007). Critical success factors for e-learning acceptance: Confirmatory factor models. Computers \& Education, 49(2), 396-413.

43. Selwyn, N. (2010). Looking beyond learning: notes towards the critical study of educational technology. 65 73. doi:10.1111/j.13652729.2009.00338

44. Tinto, V. (1993). Leaving college: Rethinking the causes and cures of student attrition (2nd ed.). Chicago: University of Chicago Press.

45. Yin, R.K. (2003) Case Study Research: Design and Methods, 3rd ed., Sage Publications, Thousand Oaks, California. 